\title{
Notes on Books
}

work, and will, no doubt, suggest new lines of investigation for those engaged in clinical research. The book is written in an exceedingly pleasant style, and-unlike many physiological works-it is relatively easy to read. A considerable portion of the book is concerned with the physiology of muscular exercise, and it is perhaps surprising to find that recent advances in gastric physiology have been excluded. Occasionally the author deals, somewhat dogmatically, with subjects which are still in the realms of controversial speculation, but a slight bias lends a flavour to an exceedingly interesting and instructive book.

Bowlby and Andrewes Surgical Pathology and Morbid Anatomy. Eighth Edition, revised by Geoffrey Keynes, M.A., M.D., F.R.C.S. Pp. $\mathrm{x}+644$, with 224 illustrations. London: J. \& A. Churchill. r930. Price 21s.

In revising this book the aim of $\mathrm{Mr}$ Keynes has been to maintain its general character, while bringing it up to date. This has necessitated the rewriting of many chapters and other alterations including an entirely new $w_{1}$ chapter on tumours of the brain and spinal cord, written by Mr J. Paterson Ross. In the reviewer's opinion the book would have been improved by still more radical alterations. In the section on acute osteomyelitis no mention is made of the metaphyses as being the primary site of the disease in bone, in fact the suggestion is that usually the lesion is a periosteal one. There are also many omissions, a few of which may be mentioned. Secondary jejunal ulcer is not referred to intestinal tuberculosis is dismissed in four lines, and no mention is made of hyperplastic tuberculosis. Diseases of the spleen are not discussed, there being only a few references to these conditions in the chapter on diseases of the lymphatic system. All these subjects seem to be worthy of consideration.

The book may meet the needs of students, for whom it was primarily written, but it cannot be considered as a modern text-book on surgical pathology.

\section{NOTES ON BOOKS}

Exercise, by A. Abrahams (Heinemann, 3s. 6d.). By different forms of Exercise, Dr Abrahams explains how to attain and maintain fitness, a state which should be associated not with torture but joy and pleasure. Although he deals with exercises in general terms yet his book should be studied by "specialised" athletes, it will keep them on an even keel. 


\section{Note}

After Consulting Hours, by Christopher Howard (Heinemann, 7s. 6d.), can be heartily recommended to the busy practitioner who likes light medical reading after his active day's work. It consists of some eight chapters of "reflections," marked by sound common sense, and expressed clearly and emphatically.

Therapeutic Uses of Infra-red Rays, by W. Annandale Troup (Actinic Press) claims to be the first book published in Britain on the use of these rays, which the author has found a "short-cut" to cure in a variety of conditions.

Minor Surgery and Bandaging, by Gwynne Williams, M.S., F.R.C.S. (Churchill, ros. 6d.). A twentieth edition is in itself sufficient indication of a book's continued popularity. The more important changes include the injection treatment of varicose veins, fuller description and illustration of the treatment of fractures, and revision of the chapter on anæsthetics. It remains a valued guide for house-surgeons and senior students.

\section{NOTE}

$A_{T}$ the Graduation Ceremonial held on rgth December r 930 the

\section{University of \\ Edinburgh.}

M.B. Vice-Chancellor, Sir Thomas Holland, conferred the degree of Doctor of Medicine on Robert Douglas Aitken, D.Sc. (S. Africa), South Africa, Enol, Ch.B., I929 (Commended for Thesis); Leslie John Davis, Z gland, M.B., Ch.B., I924 (Commended); Ian Brandon Ewart, New Zealand, M.B., Ch.B., r927; William Marsden Ford-Robertson, Scotland, M.B., Ch.B., I923 (Highly Commended); William Goldie, M.A., M.C., Scotland, M.B., Ch.B., I9I 5 ; Laura Margaret Ligertwood, Scotland, M.B., Ch.B., I92 I (Commended); Johannes Hendrik Loots, South Africa, M.B., Ch.B., I 922 ; Donald Patrick MacIver, M.C., Scotland, M.B., Ch.B., r 922 ; Milan Sokolovitch, Serbia, M.B., Ch.B., I 924 (Highly Commended); Joseph Weinstein, U.S.A., M.B., Ch.B., I927; John Hargreaves Harley Williams, England, M.B., Ch.B., I 923 (Gold Medal for Thesis); Morris Witkin, South Africa, M.B., Ch.B., I 922.

The Degrees of Bachelor of Medicine and Bachelor of Surgery were conferred on forty-four candidates. Ian Donald Grant graduated with Honours.

The Diploma in Public Health was conferred on Colin Panton Beattie, M.A., M.B., Ch.B. A Thesis Gold Medal was awarded to John Hargreaves Harley Williams, M.D., and the Ellis Prize in Physiology, to William Alexander Bain, B.Sc. 